\title{
Wood Bio-Oil Noncatalytic Gasification: Influence of Temperature, Dilution by an Alcohol and Ash Content
}

\author{
Younes Chhiti, ${ }^{* \dagger}$ Sylvain Salvador,${ }^{\dagger}$ Jean-michel Commandré, ${ }^{\dagger}$ François Broust, ${ }^{\dagger}$ and Carole Couhert ${ }^{\S}$ \\ ${ }^{\dagger}$ Ecole des Mines d'Albi - Carmaux, Centre RAPSODEE, FRE CNRS 3213, Campus Jarlard, route de Teillet 81013, \\ Albi CT Cedex 09, France, ${ }^{\star C I R A D, ~ U P R ~} 42$ Biomasse Energie, TA 10/16, 73, Avenue J.-F. Breton, 34398 Montpellier Cedex 5, \\ France, and ${ }^{\S}$ TRIFYL, Syndicat mixte départemental pour la valorisation des déchets ménagers et assimilés, \\ 81300 Labessiere-candeil, Albi, France
}

\begin{abstract}
Biomass gasification is gaining attention as a route for biomass energy production. When large scale units are considered, bio-oil shows lots of advantages compared to solid biomass such as high energy volume density and easy handling and storing. Syngas $\left(\mathrm{H}_{2}\right.$ and $\left.\mathrm{CO}\right)$ can be produced from bio-oil by two gasification processes, also called reforming processes: catalytic reforming at medium temperature and noncatalytic reforming at high temperature. In the literature, most of the works focus on the catalytic reforming and mainly concern the aqueous fraction of bio-oil or model compounds. Only very few works can be found on the noncatalytic reforming of crude bio-oil. The objectives of this work were to perform experimentally the injection and gasification of nondiluted bio-oil in a lab-scale High Temperature Entrained Flow Reactor (HT-EFR) and to determine the syngas composition and yield. The influence of temperature on the gasification process has been investigated over a wide range from 1000 to $1400{ }^{\circ} \mathrm{C}$. Hydrogen yield increases with temperature via steam reforming of $\mathrm{CH}_{4}$ and $\mathrm{C}_{2} \mathrm{H}_{2}$ and with water gas shift reaction. A thermodynamic equilibrium calculation was conducted. It shows that equilibrium is reached within several seconds at the temperature of $1400^{\circ} \mathrm{C}$. After that, experiments of gasification were realized at $1400^{\circ} \mathrm{C}$ with pure ethanol and with ethanol added bio-oil and in order to study the impact of dilution on the syngas yield. The influence of ash on the gasification process has also been evaluated. The ash seems to cause a decrease in the total amount of gas produced.
\end{abstract}

\section{Introduction}

The process of obtaining energy from conventional sources causes atmospheric pollution, resulting in problems like global warming, acid rain, etc. The development of nonconventional sources like wind, sunlight, water, biomass, etc., is inevitable. Syngas $\left(\mathrm{H}_{2}\right.$ and $\left.\mathrm{CO}\right)$ production from renewable sources such as lignocellulosic biomass can reduce the emissions of $\mathrm{SO}_{2}$ and $\mathrm{NO}_{x}$ remarkably; the $\mathrm{CO}_{2}$ neutral energy supply can also be achieved. ${ }^{1}$ Biomass gasification process is one of the main routes to produce either syngas, dedicated to second generation biofuels synthesis, or hydrogen. However, lignocellulosic biomass is a resource with variable composition, wide geographical dispersion, and low energy density. These are important drawbacks when large-scale bioenergy production units are considered. In order to minimize the impact of transport, an alternative to the direct upgrading of biomass consists of preconditioning it on decentralized sites before transportation to a centralized bioenergy production unit.

Fast pyrolysis is a thermal decomposition process operated in the absence of oxygen with the aim to convert biomass into liquid products (bio-oil) together with noncondensable gases and solid char as byproduct. For a few years, fast pyrolysis is being considered as a promising route for preconditioning biomass into bio-oil as liquid intermediate biofuel before

*To whom correspondence should be addressed. Telephone: +33(5)63493241. E-mail: ychhiti@mines-albi.fr

(1) Sharma.; Bakhshi, N. N. Catalytic upgrading of biomass-derived oils to transportation fuels and chemicals. Can. J. Chem. Eng. 1991, 69, 1071-1081. its transport to a gasification unit. Indeed, bio-oil has much higher volume energy density than that of solid biomass and could be easily stored and transported from decentralized production sites to a large-scale processing unit. A lot of works on fast pyrolysis have been reported within the last years. $^{2,3}$

The essential features to obtain high yields of bio-oil (up to $75 \mathrm{wt} \%$ on dry basis) are a moderate pyrolysis temperature $\left(500{ }^{\circ} \mathrm{C}\right)$, high heating rates $\left(10^{3}-10^{5 \circ} \mathrm{C} / \mathrm{s}\right)$, short vapor residence times $(<2 s)$, and rapid quenching of the pyrolysis vapors. A number of pyrolysis reactors have been developed, including bubbling or circulating fluid bed, rotating cone, vacuum pyrolysis reactor, ablative reactor, and twin screw reactor. ${ }^{4-6}$ Since 1990 , demonstration and precommercial units have been developed within EU and North-America.

A lot of works have also been dedicated to bio-oil characterization, upgrading, and utilization. Bio-oil is very different compared to petroleum fuels. It is necessary to develop

(2) Meier, D.; Faix, O. State of the art of applied fast pyrolysis of lignocellulosic materials - a review. Bioresour. Technol. 1999, 68, 71-7.

(3) Mohan, D.; Pittman, C. U.; Steele, P. H. Pyrolysis of wood/ biomass for bio-oil: a critical review. Energy Fuel 2006, 20, 848-89.

(4) Bridgwater, A. V.; Peacocke, G. V. C. Fast pyrolysis processes for biomass. Renewable Sustainable Energy Rev. 2000, 4, 1-73.

(5) Bridgwater, A. V.; Czernik, S.; Piskorz, J. An overview of fast pyrolysis technology. In Progress in thermochemical biomass conversion; Bridgwater, A. V., Ed.; Blackwell: Oxford, 2001; pp 977-97.

(6) Bridgwater, A. V.; Maniatis, K. The production of biofuels by the thermochemical processing of biomass. In Molecular to global photosynthesis; Archer, M. D., Barber, J., Eds.; IC Press: London, 2004; pp $521-612$. 
new technologies for their successful utilization, which requires adequate understanding of their overall fuel properties.

However, the behavior of these bio-oils within the gasification reactor also called reforming reactor has been hardly studied so far in the literature, and the improvement of the scientific knowledge is necessary to the emergence of this route. A number of experimental studies devoted to bio-oil combustion brought some knowledge about the behavior of a single droplet when heated and submitted to a reactive atmosphere.

Calabria and Alessio carried out lots of studies on the combustion behaviors of fiber-suspended single bio-oil droplets. The droplet size varied between 300 and $1100 \mu \mathrm{m}$ and the furnace temperature changed in the range of $400-1200{ }^{\circ} \mathrm{C}$. The droplets were observed to undergo initial heating, swelling, and microexplosion before ignition. During this stage, the temperature-time curves showed two zones with constant temperatures $\left(100\right.$ and $450{ }^{\circ} \mathrm{C}$ ), which corresponded to the evaporation of light volatiles and the thermal cracking of unstable components, respectively. The droplets were ignited at around $600^{\circ} \mathrm{C}$. The combustion of the droplets started with an enveloping blue flame. Then, the flame developed a yellow tail with its size increasing, which indicated the formation of soot. After that, the flame shrank and extinguished, and the remaining solid carbonaceous residues burned leading to the formation of ash. ${ }^{8-10}$

Various pathways can be used for the production of hydrogen and hydrogen-rich gases from biomass: anaerobic digestion, fermentation, metabolic processing, high pressure supercritical conversion, gasification, and pyrolysis. ${ }^{1-13}$ Among them gasification appear to be the most feasible. The combination of fast pyrolysis of biomass followed by transportation in large units for steam reforming has attracted considerable attention of the research community, as one of the most promising viable methods for hydrogen production.

In air/steam gasification process the essential steps are pyrolysis, partial oxidation, cracking of tar, solid carbon residue gasification, reforming (steam and/or dry), and water gas shift to yield syngas, water, carbon dioxide, and unwanted products like tars, methane, and carbon. ${ }^{14}$ As a summary, a schematic representation of air/steam gasification of single droplet of bio-oil is proposed in Figure 1.

1. 1. Steam Reforming of Bio-Oil. The steam reforming of the bio-oil can be simplified as the steam reforming of an

(7) Oasmaa, A.; Czernik, S. Fuel oil quality of biomass pyrolysis oils - state of the art for the ender users. Energy Fuel 1999, 13, 914-21.

(8) Calabria, R.; Chiariello, F.; Massoli, P. Combustion fundamentals of pyrolysis oil based fuels. Exp. Therm. Fluid Sci. 2007, 31, 413-20.

(9) Allessio, J. D.; Lazzaro, M.; Massoli, P.; Moccia, V. In Thermooptical investigation of burning biomass pyrolysis oil droplets. Twentyseventh symposium (international) on combustion. The Combustion Institute: Pittsburgh, 1998; pp 1915-22.

(10) Calabria, R.; Allessio, J. D.; Lazzaro, M.; Massoli, P.; Moccia, V. Bio-fuel oil. Upgrading by hot filtration and novel physical methods. Task 5: fundamental behavior of BFO in combustion; Final report, JOR3-CT97-0253; 2000.

(11) Milne, T. A.; Elam, C. C.; Evans, R. J. Hydrogen from biomass, State of the art and research challenges; National Renewably Energy Laboratory: Golden, CO, USA, IEA/H2/TR-02/001.

(12) Ni, M.; Leung, D. Y. C.; Leung, M. K. H.; Sumathy, K. An overview of hydrogen production from biomass. Fuel Process. Technol. 2006, 87 (5), 461-72.

(13) Antonakou, E.; Lappas, A.; Nilsen, M.; Bouzga, A.; Stocker, M. Evaluation of various types of Al-MCM-41 materials as catalysts in biomass pyrolysis for the production of bio-fuels and chemicals. Fuel 2006, 85 (14-15), 2202-12.

(14) Levenspiel, O. What will come after petroleum. Ind. Eng. Chem. Res. 2005, 44, 5073. oxygenated organic compounds $\left(\mathrm{C}_{\mathrm{n}} \mathrm{H}_{\mathrm{m}} \mathrm{O}_{\mathrm{k}}\right)$ following

$$
\mathrm{C}_{\mathrm{n}} \mathrm{H}_{\mathrm{m}} \mathrm{O}_{\mathrm{k}}+(\mathrm{n}-\mathrm{k}) \mathrm{H}_{2} \mathrm{O} \leftrightarrow \mathrm{nCO}+(\mathrm{n}+\mathrm{m} / 2-\mathrm{k}) \mathrm{H}_{2}
$$

During the past decade, catalytic steam reforming of biooil components has been widely studied, focusing on acetic acid as one of the most representative compounds.

Production of hydrogen from catalytic steam reforming of bio-oil was extensively investigated by NREL. ${ }^{15,16}$ Czernik et al. obtained hydrogen in a fluidized bed reactor from the carbohydrate derived fraction of wood bio-oil with a yield of about $80 \%$ of theoretical maximum. ${ }^{17}$ The catalytic steam reforming of the bio-oil or the model oxygenates (e.g., ethanol, acetic acid) has been widely explored via various catalysts, e.g., Ni-based catalysts, ${ }^{18} \mathrm{Mg}$-doped catalysts, ${ }^{19}$ and noble metal-loaded catalysts. ${ }^{20-22} \mathrm{~A}$ lower steam-to-carbon ratio $(\mathrm{S} / \mathrm{C})$ and a lower reforming temperature are essential from the viewpoint of economy. Noble metals $(\mathrm{Pt}, \mathrm{Ru}, \mathrm{Rh})$ are more effective than the Ni-based catalysts and less carbon depositing. Such catalysts are not common in real applications because of their high cost. Catalytic steam reforming of bio-oil is a costly process and presents several disadvantages such as carbon deposit and the deactivation of catalysts due to coke or oligomer deposition even in the presence of an excess of steam $(\mathrm{S} / \mathrm{C}>5) .{ }^{20,23}$ For these reasons, there is an interest in developing noncatalytic gasification of bio-oil, which is the propose of this work.

Only very few works can be found on the noncatalytic reforming of whole bio-oil. Bimbela et al. studied catalytic and noncatalytic steam reforming of acetol (bio-oil model compound) in fixed bed at low temperature $\left(550-750^{\circ} \mathrm{C}\right)$ in order to highlight the specific role of the catalyst in this process. ${ }^{24}$ The same study is carried out by Guus van Rossum et al. concerning catalytic and noncatalytic gasification of bio-oil in a fluidized bed over a wide temperature range $\left(523-914{ }^{\circ} \mathrm{C}\right) .{ }^{25}$ Marda et al. has developed a system for the volatilization and conversion of a bio-oil mixed with methanol to syngas via noncatalytic partial oxidation (NPOX) using an ultrasonic nozzle to feed the mixture. The effects of

(15) Wang, D.; Czernik, S.; Montane, D. Biomass to hydrogen via pyrolysis and catalytic steam reforming of the pyrolysis oil and its fractions. Ind. Eng. Chem. Res. 1997, 36, 1507-18.

(16) Wang, D.; Czermik, S.; Chornet, E. Production of hydrogen from biomass by catalytic steam reforming of fast pyrolytic oils. Energy Fuels 1998, 12, 19-24.

(17) Czernik, S.; French, R.; Feik, C. Hydrogen by catalytic steam reforming of liquid byproducts from biomass thermoconversion processes. Ind. Eng. Chem. Res. 2002, 41, 4209-15.

(18) Sakaguchi, M.; Watkinson, P. A.; Ellis, N. Steam Gasification of Bio-Oil and Bio-Oil/Char Slurry in a Fluidized Bed Reactor. Energy Fuels 2010, 24, 5181-5189.

(19) Garcia, L.; French, R.; Czernik, S.; Chornet, E. Catalytic steam reforming of bio-oils for the production of hydrogen: effects of catalyst composition. Appl. Catal. 2000, 201, 225-239.

(20) Trimm, D. L. Coke formation and minimization during steam reforming reactions. Catal. Today 1997, 37, 233-238.

(21) Rioche, C.; Kulkarni, S.; Meunier, F. C.; Breen, J. P.; Burch, R. Steam reforming of model compounds and fast pyrolysis bio-oil on supported noble metal catalysts. Appl. Catal. 2005, 61, 130-139.

(22) Goula, M. A.; Kontou, S. K.; Tsiakaras, P. E. Hydrogen production by ethanol steam reforming over a commercial $\mathrm{Pd} / \gamma-\mathrm{Al} 2 \mathrm{O} 3$ catalyst. Appl. Catal. 2004, 49, 135-144.

(23) Rostrup-Nielsen, J. R. Industrial relevance of coking Catal. Today 1997, 37, 225-23.

(24) Bimbela, F.; Oliva, M.; Ruiz, J.; Garcia, L.; Arauzo, J. Catalytic steam reforming of model compounds of biomass pyrolysis liquids in fixed bed: Acetol and n-butanol. J. Anal. Appl. Pyrolysis Vol. 85, Issues 1-2, May 2009, 204-213.

(25) van Rossum, G.; Kersten, S. R. A.; van Swaaij, W. P. M. Catalytic and Noncatalytic Gasification of Pyrolysis Oil. Ind. Eng. Chem. Res. 2007, 46, 3959-3967. 


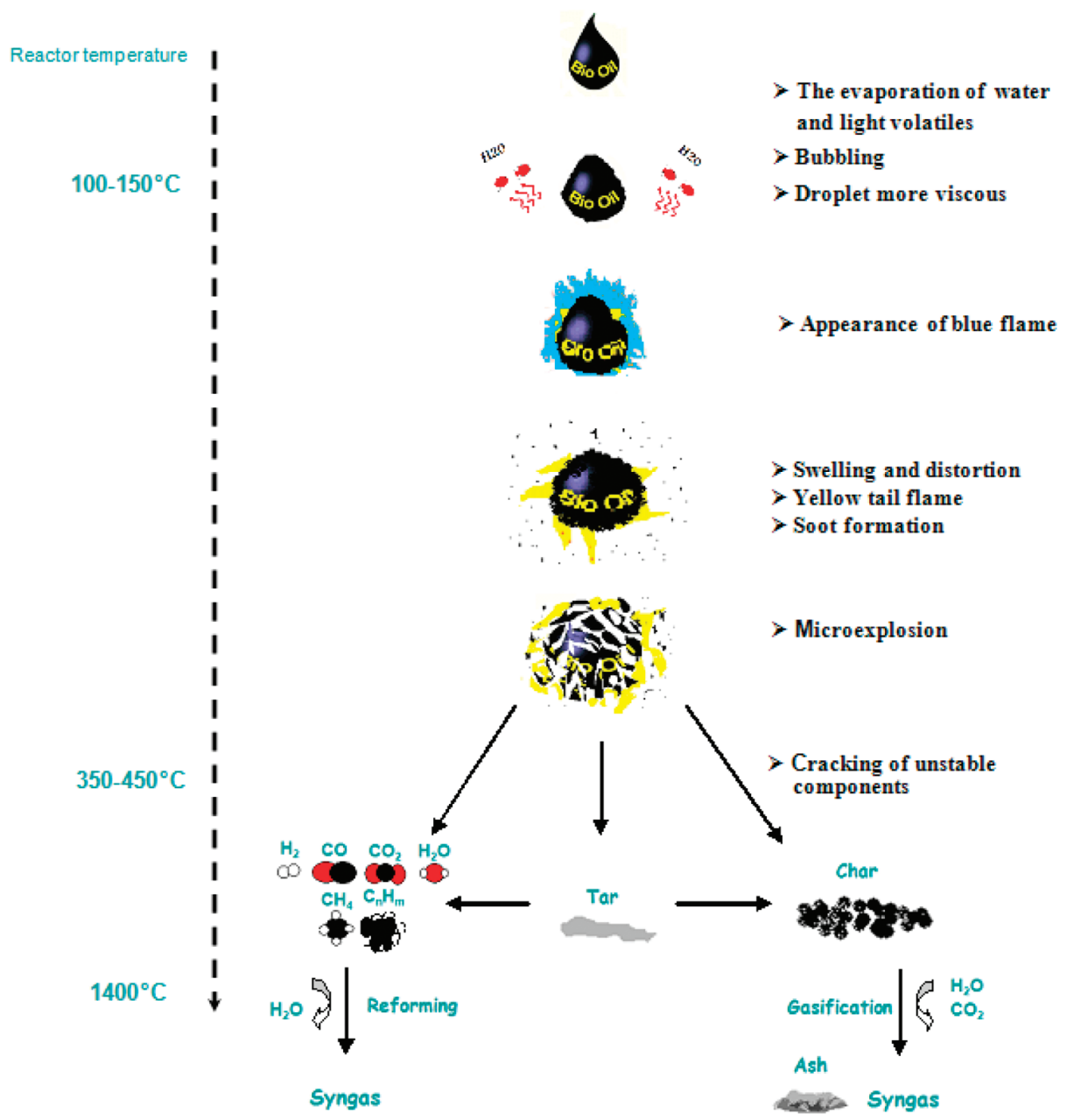

Figure 1. Schematic representation of air steam gasification of bio-oil droplet.

both temperature (from 625 to $850{ }^{\circ} \mathrm{C}$ ) and added oxygen (effective $\mathrm{O} / \mathrm{C}$ ratio from 0.7 to 1.6 ) on the yields of $\mathrm{CO}$ and $\mathrm{H}_{2}$ have been explored. They obtained hydrogen yield of about $75 \%$ of theoretical maximum. ${ }^{26}$ Panigrahi et al. gasified biomass-derived oil (BDO) to syngas and gaseous fuels at $800{ }^{\circ} \mathrm{C}$. They obtained syngas $\left(\mathrm{H}_{2}+\mathrm{CO}\right)$ yield ranging from 75 to $80 \mathrm{~mol} \mathrm{\% .}{ }^{27}$ Henrich et al. gasified lignocellulosic biomass. The first process step is a fast pyrolysis at atmospheric pressure, which produces large condensate, that was mixed to a slurries. The slurries are pumped into a slagging entrained flow gasifier and are atomized and converted to syngas at high operating temperatures and pressures. ${ }^{28}$

The present study is focused on the noncatalytic steam reforming in the absence of $\mathrm{O}_{2}$ of whole wood bio-oil in a High Temperature Entrained Flow Reactor (HT-EFR). The objectives of this work are to determine the syngas yield and composition as a function of temperature and to carry in parallel a thermodynamic equilibrium calculation to determine the temperature at which the thermodynamic equilib-

(26) Marda, J. R.; DiBenedetto, J.; McKibben, S.; Evans, R. J.; Czernik, S.; French, R. J.; Dean, A. M. Non-catalytic partial oxidation of bio-oil to synthesis gas for distributed hydrogen production. Int. J. Hydrogen Energy 2009, 34, 8519-8534.

(27) Panigrahi, S.; Dalai, A. K.; Chaudhari, S. T.; Bakhshi, N. N. Synthesis Gas Production from Steam Gasification of Biomass-Derived Oil. Energy Fuels 2003, 17, 637-642.

(28) Henrich, E.; Weirich, F. Pressurized Entrained Flow Gasifiers for Biomass. Environ. Eng. Sci. 2004, 21, 53-64. rium is reached. Moreover, the impact of bio-oil alcoholdilution on the syngas yield has been investigated. Finally the influence of ash on the reforming process has also been evaluated.

\section{Materials and Methods}

2.1. Description of Experimental Device. The steam reforming experiments of bio-oils were carried out in a laboratory scale HT-EFR. It consists in a vertical tubular reactor electrically heated by a total $18 \mathrm{~kW}$ three-zones electrical furnace and is able to reach $1600{ }^{\circ} \mathrm{C}$ in a $1 \mathrm{~m}$ long isothermal reaction zone, as illustrated in Figure 2. The atmosphere gas is generated by feeding the controlled flows of water and nitrogen in a $2 \mathrm{~kW}$ electrical steam generator. This atmosphere gas is then preheated to $900{ }^{\circ} \mathrm{C}$ using a $2.5 \mathrm{~kW}$ electrical battery of heating elements before reaching the isothermal reaction zone. The HT-EFR was initially set up to achieve high heating-rate gasification of solid biomass and was equipped for the present work with a specially designed bio-oil pulverization feeder, with the aim to obtain a very constant mass flow rate spray. ${ }^{29}$

The feeder consists of a $1 \mathrm{~m}$ long and $14 \mathrm{~mm}$ o.d. probe cooled with water at $50{ }^{\circ} \mathrm{C}$. At its extremity a stainless steel

(29) Couhert, C.; Commandre, J. M.; Salvador, S. Is it possible to predict gas yields of any biomass after rapid pyrolysis at high temperature from its composition in cellulose, hemicellulose and lignin. Fuel 2009, $88,408-417$. 


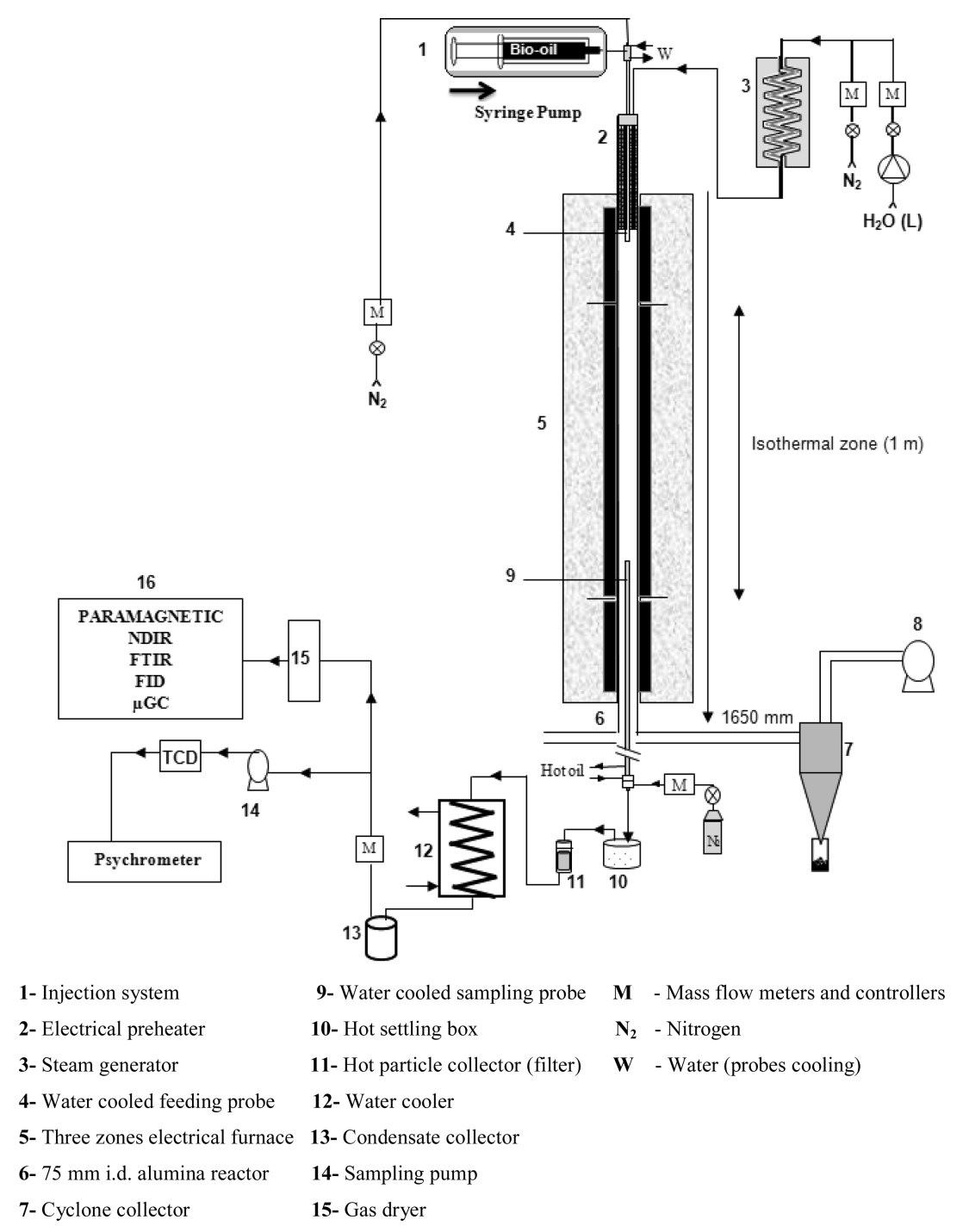

Figure 2. Schematic view of the entrained flow reactor of Ecole des Mines d'Albi.

nozzle is integrated. Which allows uniform distribution with fine atomization. Nozzle type (DELAVAN WDB) is a solid cone, with orifice diameter of $0.46 \mathrm{~mm}$ and a spray angle of $60^{\circ}$.

The oil is fed with a syringe which is pushed automatically. The expected mass flow rate of $0.3 \mathrm{~g} / \mathrm{min}$ was too low for direct pulverization. Therefore, a $3.5 \mathrm{NL} / \mathrm{min} \mathrm{N}_{2}$ flow rate was used to entrain oil in the feeding probe and to ensure a thin spray of the oil. The spray of droplets is dispersed on the section of a $75 \mathrm{~mm}$ i.d. alumina reactor swept by $16 \mathrm{NL} / \mathrm{min}$ of an atmosphere gas containing $10 \mathrm{vol} . \%$ of steam in $\mathrm{N}_{2}$. The steam to fuel mass ratio (fuel includes inherent water in bio-oil) was $\mathrm{S} / \mathrm{F}=4.5$, which is equivalent to steam to carbon molar ratio of $\mathrm{S} / \mathrm{C}=8.3$.

Steam reforming takes place along the reactor during a controlled vapor residence time, which was about $3 \mathrm{~s}$. The gas residence time is calculated as ratio of the reaction zone to the average gas velocity in the reactor. At $1760 \mathrm{~mm}$ downstream of the injection point, gases and solid residue were sampled by a hot-oil cooled probe. Gas and solid residue were separated using a settling box and a filter, both heated to avoid water condensation. The water and potential remaining tars were first condensed in a heat exchanger, and noncondensable gases were forwarded to a microchromatograph analyzer $(\mu \mathrm{GC})$ to quantify $\mathrm{H}_{2}, \mathrm{CO}, \mathrm{CO}_{2}, \mathrm{CH}_{4}, \mathrm{C}_{2} \mathrm{H}_{2}$, $\mathrm{C}_{2} \mathrm{H}_{4}, \mathrm{C}_{2} \mathrm{H}_{6}, \mathrm{C}_{3} \mathrm{H}_{8}$, and $\mathrm{C}_{6} \mathrm{H}_{6}$.

Gases were also analyzed by other analyzers that allowed to check the absence of $\mathrm{O}_{2}$, to confirm the analysis, and to control continuously gas production during the gasification: a Fourier Transform InfraRed (FTIR) analyzer, a Non-Dispersive InfraRed (NDIR) analyzer coupled with a paramagnetic analyzer for $\mathrm{O}_{2}$, and a Thermal Conductivity Detector (TCD) to quantify $\mathrm{H}_{2}$.

2.2. Feedstock. The feedstock used for all experiments is a bio-oil produced by fast pyrolysis of hardwood on an industrial-scale fluidized bed unit (provided indirectly through CIRAD, France). Its physicochemical properties have been measured (see Table 1). The water content of the bio-oil measured by Karl Fischer method (ASTM E203) is around $26 \mathrm{wt} \%$ which is in agreement with the average values reported in the literature. It can be noticed that the solid particles content is rather high $(2.34 \mathrm{wt} \%)$, while the ash content remains low (around $0.06 \mathrm{wt} \%$ ). This confirms that the solid particles mainly consist of high-carbon content char particles. These particles were entrained by the gas stream to the bio-oils condensers. Ultimate analysis and LHV of the bio-oil are very 
Table 1. Ultimate Analysis and Several Characteristics of Bio-Oil Derived from Hardwood Fast Pyrolysis

\begin{tabular}{|c|c|c|c|c|c|c|c|c|}
\hline \multicolumn{4}{|c|}{ ultimate analysis (wt \%) } & \multirow[b]{2}{*}{$\mathrm{H}_{2} \mathrm{O}(\mathrm{wt} \%)$} & \multirow[b]{2}{*}{ ash (wt \%) } & \multirow[b]{2}{*}{ solids (wt \%) } & \multirow[b]{2}{*}{$\mathrm{LHV}(\mathrm{MJ} / \mathrm{kg})$} & \multirow[b]{2}{*}{ kinematic viscosity at $20^{\circ} \mathrm{C}\left(\mathrm{mm}^{2} \cdot \mathrm{s}^{-1}\right)$} \\
\hline $\mathrm{C}$ & $\mathrm{H}$ & $\mathrm{O}$ & $\mathrm{N}$ & & & & & \\
\hline 42.9 & 7.1 & 50.58 & $<0.10$ & 26.0 & 0.057 & 2.34 & 14.5 & 103 \\
\hline
\end{tabular}

similar to those of wood. The LHV is measured according to the NF M 07-030 standard, which is technically equivalent to the ASTM D240 standard.

From the ultimate analysis, the chemical formula of the bio-oil can be established as $\mathrm{CH}_{1.18} \mathrm{O}_{0.48} \cdot 0.4 \mathrm{H}_{2} \mathrm{O}$.

The bio-oil was stored in a refrigerator. Before experiments, it was heated and filtered on a $30 \mu \mathrm{m}$ sieve to eliminate larger solid particles; this represented less than $0.01 \% \mathrm{wt}$.

\section{Results and Discussion}

3.1. Effect of Temperature. The first objective was to study the influence of temperature - over a wide range - on the syngas yield and composition.

Generally the gas mixture formed from catalytic reforming of bio-oil is composed of hydrogen, carbon monoxide and dioxide, methane, acetylene, unconverted steam, coke (carbon), and soot. Figure 3 presents the mole fraction of the gaseous products from this work (in dry basis and without $\mathrm{N}_{2}$ ) as a function of temperature in the range 1000 to $1400^{\circ} \mathrm{C}$. Error bars were established by repeating each test 2 or 3 times. The species $\mathrm{C}_{2} \mathrm{H}_{4}, \mathrm{C}_{2} \mathrm{H}_{6}, \mathrm{C}_{3} \mathrm{H}_{8}$, and $\mathrm{C}_{6} \mathrm{H}_{6}$ are not detected by chromatograph. Whatever the operating temperature between 1000 and $1300^{\circ} \mathrm{C}$, bio-oil is mainly decomposed to $\mathrm{H}_{2}, \mathrm{CO}, \mathrm{CO}_{2}, \mathrm{CH}_{4}$, and $\mathrm{C}_{2} \mathrm{H}_{2}$. Above $1300{ }^{\circ} \mathrm{C} \mathrm{C}_{2} \mathrm{H}_{2}$ disappears, while $\mathrm{CH}_{4}$ disappears above $1400{ }^{\circ} \mathrm{C}$. As the temperature rises, the fraction of $\mathrm{H}_{2}$ increases monotonically at the expense of carbon monoxide, methane, and acetylene. Above $1300{ }^{\circ} \mathrm{C}$ the hydrogen content remains almost stable. At $1400{ }^{\circ} \mathrm{C}$ hydrogen mole fraction reaches the maximum value of $64 \mathrm{~mol} \%$ of the syngas.

The reactions that may explain the increase of hydrogen with temperature are

-The steam reforming of $\mathrm{CH}_{4}$ and $\mathrm{C}_{2} \mathrm{H}_{2}$ into $\mathrm{H}_{2}$ and $\mathrm{CO}$

-The water gas shift reaction $\mathrm{CO}+\mathrm{H}_{2} \mathrm{O} \leftrightarrow \mathrm{CO}_{2}+\mathrm{H}_{2}$

The water gas shift reaction can also explain the increase of carbon dioxide and the decrease of carbon monoxide between 1000 and $1200{ }^{\circ} \mathrm{C}$. Above $1200{ }^{\circ} \mathrm{C}$, carbon monoxide slightly increases. This may be explained by steam gasification of the solid carbon residue resulting from the pyrolysis of oil droplets to yield carbon monoxide and hydrogen following the reaction

$$
\mathrm{C}+\mathrm{H}_{2} \mathrm{O} \leftrightarrow \mathrm{CO}+\mathrm{H}_{2}
$$

and potentially following the Boudouard reaction which would explain the slight decrease of $\mathrm{CO}_{2}$

$$
\mathrm{C}+\mathrm{CO}_{2} \rightarrow 2 \mathrm{CO}
$$

It was observed that as the temperature increases the amount of collected solid decreases significantly above $1000^{\circ} \mathrm{C}$. The process allows achieving very high heating rate

(30) Van de Steene, L.; Salvador, S.; Charnay, G. Controlling powdered fuel combustion at low temperature in a new entrained flow reactor. Combust. Sci. Technol. 2000, 159, 255-279.

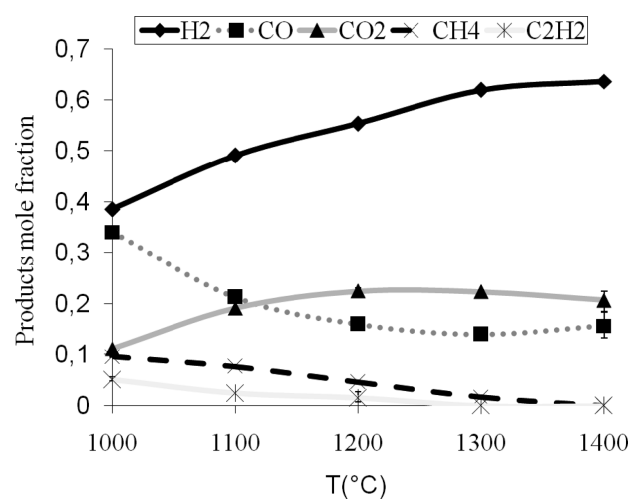

Figure 3. Composition of the produced syngas (dry basis and without $\mathrm{N}_{2}$ ) - effect of temperature, at $\mathrm{S} / \mathrm{F}=4.5$.

estimated at $2000{ }^{\circ} \mathrm{C} \cdot \mathrm{s}^{-1} \cdot{ }^{30}$ In these conditions, the char yield measured is very low: $<1 \mathrm{wt} \%$. At $1400^{\circ} \mathrm{C}$ more than the $99.9 \%$ the bio-oil is converted to gas.

3.2. Equilibrium Calculation. The thermodynamic equilibrium calculation is independent of reactor to predict the yield of final products, based on the minimization of the Gibbs free energy of the system. It was conducted here using FactSage software 5.4. to establish whether the syngas was closed or not to equilibrium at the different temperatures. Operating temperature varied from 1000 to $1400{ }^{\circ} \mathrm{C}$; pressure was fixed at $1 \mathrm{~atm}$. The software is not presented in detail in this paper; details of the thermodynamic calculation could be found in FactSage Web site. ${ }^{31}$

The results of prediction are presented in Figure 4, expressed in $\mathrm{g}$ of gas produced per $\mathrm{g}$ of crude bio-oil injected. As the temperature increases from 1000 to $1400^{\circ} \mathrm{C}$ the calculated equilibrium yield of $\mathrm{H}_{2}$ remains approximately constant at $0,11 \mathrm{~g} / \mathrm{g}$, while the yield of $\mathrm{CO}$ increases from 0.3 at $1000{ }^{\circ} \mathrm{C}$ to $0.45 \mathrm{~g} / \mathrm{g}$ at $1400{ }^{\circ} \mathrm{C}$. The $\mathrm{CO}_{2}$ yield decrease from $1.1 \mathrm{~g} / \mathrm{g}$ at $1000{ }^{\circ} \mathrm{C}$ down to 0.9 at $1400{ }^{\circ} \mathrm{C}$.

At $1000{ }^{\circ} \mathrm{C}$ the calculation yields are far away from the experimental results. The deviation from equilibrium at lower temperatures is also reported by Sakaguchi et al. ${ }^{18}$ At $1200{ }^{\circ} \mathrm{C}$ the thermodynamic equilibrium begins to establish. The calculation nevertheless does not retrieve the presence of $\mathrm{CH}_{4}$ and $\mathrm{C}_{2} \mathrm{H}_{2}$. At $1400{ }^{\circ} \mathrm{C}$ the experimental yields are very closed to the equilibrium calculation yields: 0.11 and 0.12 respectively for $\mathrm{H}_{2}, 0.45$ and 0.45 respectively for $\mathrm{CO}$, and 0.86 and 0.88 respectively for $\mathrm{CO}_{2}$. It can be concluded that at this temperature the equilibrium is reached.

It is also interesting to compare the obtained experimental yields at $1400{ }^{\circ} \mathrm{C}$ to theoretical yields corresponding with complete gasification of oil that would follow

$$
\mathrm{CH}_{1.18} \mathrm{O}_{0.48} \cdot 0.4 \mathrm{H}_{2} \mathrm{O}+1.12 \mathrm{H}_{2} \mathrm{O} \rightarrow \mathrm{CO}_{2}+2.11 \mathrm{H}_{2}
$$

The maximum stoichiometric $\mathrm{H}_{2}$ yield for this oil would be $0.150 \mathrm{~g}$ per $1 \mathrm{~g}$ crude bio-oil, while a value of $0.126 \mathrm{~g}$ was

(31) Thermfact Ltd. \& GTT-Technologies GmbH. http://www. factsage.com/ (accessed 2006). 

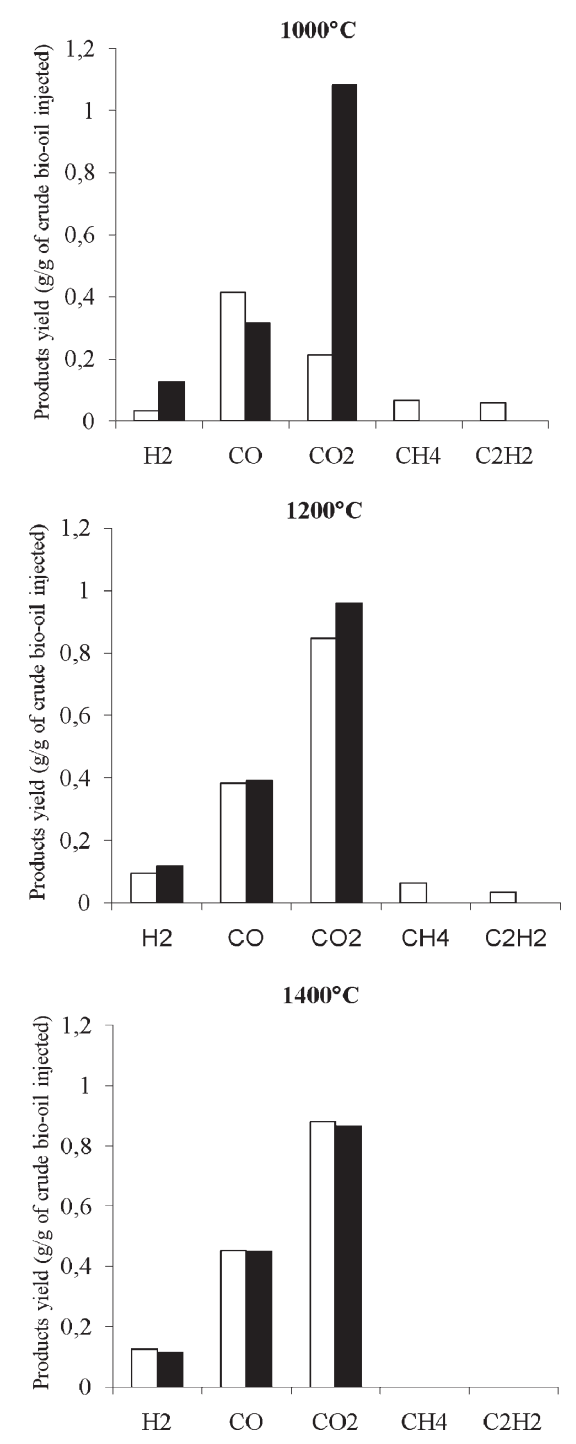

Figure 4. Gas yield from bio-oil reforming at 1000,1200 , and $1400{ }^{\circ} \mathrm{C}$, $\mathrm{S} / \mathrm{F}=4.5$.

obtained experimentally. This shows that in our experimental conditions and at $1400^{\circ} \mathrm{C}$ steam reforming of bio-oil lead to a production of $\mathrm{H}_{2}$ with a yield of about $84 \%$ of theoretical maximum.

3.3. Effect of Dilution by a Solvent. Most of the published works of steam reforming concern the aqueous fraction of bio-oil, model compounds, or a mixture of bio-oil/solvent. This choice is essentially linked to injection problems of the very viscous bio-oil. The injection of a mixture bio-oil/solvent is a classical way to facilitate nebulization of crude bio-oil and to avoid injection plugging. It was therefore decided in this work to study the gasification of alcohol added bio-oil in order to evaluate the impact of dilution on the syngas yield. Bio-oil and ethanol were simply mixed and agitated in a container. The two components appear to be miscible; no segregation was observed even after storage. Figure 5 shows the gas yields of steam reforming of crude bio-oil, $75 / 25 \%$ bio-oil/ethanol mixture, $50 / 50 \%$ bio-oil/ethanol mixture, and pure ethanol at $1400{ }^{\circ} \mathrm{C}$. We can notice that the hydrogen and carbon monoxide yield increases when we increase the fraction of ethanol in crude bio-oil, while $\mathrm{CO}_{2}$ remains more or less constant, $\mathrm{CH}_{4}$ and $\mathrm{C}_{2} \mathrm{H}_{4}$ were not present in the produced gas at $1400{ }^{\circ} \mathrm{C}$.

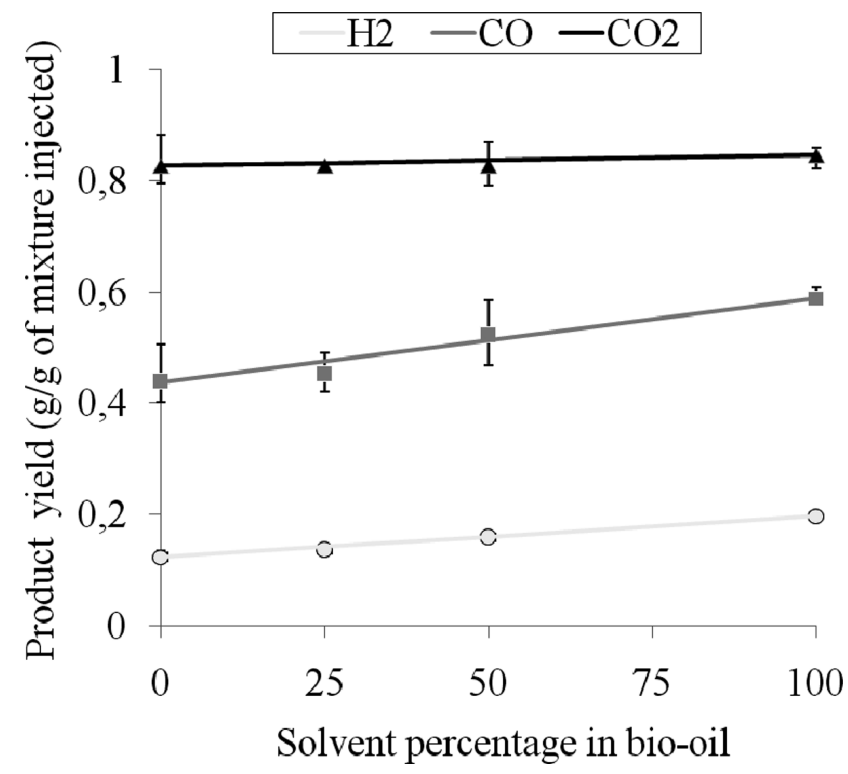

Figure 5. Yield of $\mathrm{H}_{2}, \mathrm{CO}$, and $\mathrm{CO}_{2}$ during gasification at $1400{ }^{\circ} \mathrm{C}$ and $\mathrm{S} / \mathrm{F}=4.5$ of crude bio-oil with different dilutions $\left(\mathrm{CH}_{4}\right.$ and $\mathrm{C}_{2} \mathrm{H}_{4}$ were not present in the produced gas at $1400{ }^{\circ} \mathrm{C}$ ).

Considering the yield of pure ethanol and crude bio-oil, we can observe that the $\mathrm{H}_{2}$ and $\mathrm{CO}$ yields seem to follow an additivity law: theoretical yields as calculated from an additivity law fit with experimental yields of gasification products. Some dispersion can be observed concerning CO yields. Nevertheless, the difference between experimental results and calculated values remain smaller than experimental error bars. This validates an additivity law. The fact that an additivity law is observed cannot be interpreted as a noninteraction between bio-oil and the solvent along the primary pyrolysis step, but rather by the fact that at high temperature and closed to equilibrium conditions the composition of the gas tends toward a sum of the gas that would be produced from bio-oil and solvent separately. This result essentially allows to trace a crude bio-oil behavior if it is diluted in a solvent.

3.4. Effect of Ash. Ash is known for their catalytic effect during thermo-chemical conversion of biomass, as previously approved the works done on solid biomass. They indicated that biomass ash acted catalytically and specifically in tar steam reforming; it lowered the temperature of steam reforming reactions during gasification. ${ }^{32,33}$

The aim of this part was to evaluate the potential influence of the presence of mineral matter on yields of final products from bio-oil gasification. Crude bio-oil containing $0.057 \%$ of minerals and crude bio-oil with $3 \%$ of ash were prepared to highlight effect of minerals in gasification process. The added ash is prepared by burning crushed beech wood (particle size of $300-400 \mu \mathrm{m}$ ) in a furnace equipped with 3 drawers at $600^{\circ} \mathrm{C}$. The choice of this temperature is designed to perform a $\ll$ mild $\gg$ heat treatment in order to preserve the initial properties of minerals present in the biomass, as in

(32) Skoulou, V.; Kantarelis, E.; Arvelakis, S.; Yang, W.; Zabaniotou, A. Effect of biomass leaching on $\mathrm{H}_{2}$ production, ash and tar behavior during high temperature steam gasification (HTSG) process. Int. J. Hydrogen Energy 2009, 34, 5666-5673.

(33) Masek, O.; Sonoyama, N.; Ohtsubo, E.; Hosokai, S.; Li, C. Z.; Chiba, T. Examination of catalytic roles of inherent metallic species in steam reforming of nascent volatiles from the rapid pyrolysis of brown coal. Fuel Process. Technol. 2007, 88, 179-85. 


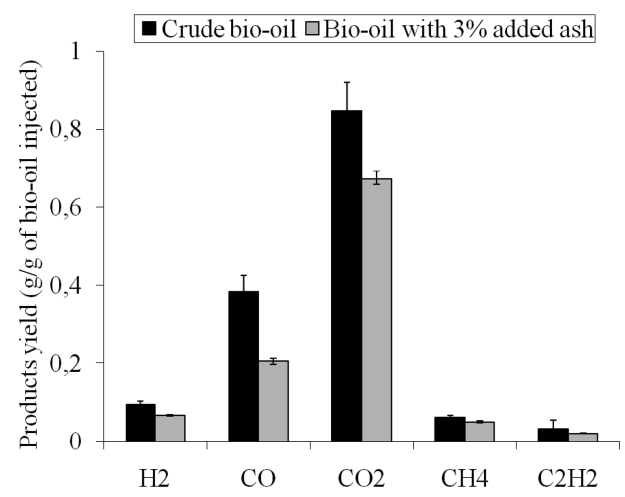

Figure 6. Yield of gas species during gasification of crude bio-oil and crude bio-oil with $3 \%$ of ash at $1200^{\circ} \mathrm{C}$ and $\mathrm{S} / \mathrm{F}=4.5$ - effect of ash on product yield.

Table 2. Composition of Ashes (from Combustion of Wood) [wt \%, Dry Ashes]

\begin{tabular}{cccccccc}
\hline $\mathrm{Ca}$ & $\mathrm{K}$ & $\mathrm{Mn}$ & $\mathrm{Mg}$ & $\mathrm{P}$ & $\mathrm{Ni}$ & $\mathrm{Na}$ & $\mathrm{Al}$ \\
\hline 11.67 & 3.80 & 1.74 & 1.54 & 1.01 & 0.25 & 0.24 & 0.10
\end{tabular}

the case of the production of bio-oil by pyrolysis. The wood is distributed in the drawers on a thin layer of $1.5 \mathrm{~cm}$ thickness to ensure good heat transfer and air diffusion. Air was fed to the reactor at low flow rate, $30 \mathrm{NL} / \mathrm{h}$, to avoid ignition and high temperature rapid combustion of wood.

The analysis of the elements most cited in literature was performed in the prepared ash. Silica, especially, is an important element that reacts easily with alkali metals and creates fusion and deposition problems during combustion and gasification. ${ }^{34}$ Calcium is present in considerable amount in ash, while potassium is at lower amounts quite volatile at high temperature. Trace elements $\mathrm{Fe}, \mathrm{Ni}$, and $\mathrm{Al}$, are known to get involved in various steam reforming reactions during gasification. ${ }^{33,35}$ The ash components were quantified by ICP, presented in Table 2. It can be noticed that $\mathrm{Ca}, \mathrm{K}, \mathrm{Mg}$, and $\mathrm{Mn}$ are present in high concentration. Other minority elements such as $\mathrm{Co}, \mathrm{Cr}, \mathrm{Cu}, \mathrm{Fe}, \mathrm{Pb}, \mathrm{Si}, \mathrm{Zn}$, and $\mathrm{Cd}$ are present in much lower concentration.

The gasification temperature of $1200{ }^{\circ} \mathrm{C}$ was chosen, because as demonstrated before at this temperature the equilibrium is not reached. Error bars were established by repeating each test 2 or 3 times. Figure 6 shows the obtained gas

(34) Arvelakis, S.; Koukios, E. G. Physicochemical upgrading of agroresidues as feedstocks for energy production via thermochemical conversion methods. Biomass Bioenergy 2002, 22, 331-8.

(35) Zhang, R.; Wang, Y.; Robert, C. Brown Steam reforming of tar compounds over $\mathrm{Ni}$ /olivine catalysts doped with $\mathrm{CeO} 2$. Energy Convers. Manage. 2007, 48, 68-77. yields from "crude bio-oil" and "crude bio-oil $+3 \%$ beech ash". Surprisingly one can notice a clear decrease in the yields of all gas species when the amount of ash is increased. The results are expressed in $g$ of gas produced per $g$ of ash free crude bio-oil injected. Among them, the $\mathrm{H}_{2}$ yield decreases from 0.094 to $0.067 \mathrm{~g} / \mathrm{g}$. $\mathrm{CO}$ and $\mathrm{CO}_{2}$ yields decreased significantly: from 0.38 to $0.20 \mathrm{~g} / \mathrm{g}$ and from 0.84 to $0.67 \mathrm{~g} / \mathrm{g}$, respectively. An explanation could be that added minerals favor polymerization reactions. These reactions lead to the formation of larger quantity of carbonaceous solid residue that is not gasified, causing a decrease in the amount of produced gas, especially $\mathrm{CO}$ and $\mathrm{CO}_{2}$.

At the high gasification temperature, volatilization of alkalies probably played a negative role on ash catalytic effect. The fact that ash did not favor gas formation at the temperature of $1200{ }^{\circ} \mathrm{C}$ could also be explained by the work of Masek et al. ${ }^{33}$ who pointed out ash deactivation at $950{ }^{\circ} \mathrm{C}$. Such a high temperature was shown to accelerate iron sintering leading to a loss of $\mathrm{Fe}$ dispersion. ${ }^{32}$

\section{Conclusions}

Whole bio-oil was successfully steam reformed in a labscale High Temperature Entrained Flow Reactor. The reaction temperature has a significant influence on the process. An increase in the reaction temperature implies higher hydrogen yield and higher solid carbon conversion. A thermodynamic equilibrium calculation showed that equilibrium is reached at $1400{ }^{\circ} \mathrm{C}$ but not at $1300{ }^{\circ} \mathrm{C}$ and below for residence times of about $3 \mathrm{~s}$.

The gasification of mixtures bio-oil/alcohol showed that the yields of gas follow an additivity law based on the yields of solvent and of bio-oil.

When adding ash to bio-oil, it has been observed a strong decrease in gas yield, while an increase was expected as in the case of catalytic process. Ash may favor polymerization reactions, causing a decrease in the yield of gas. The volatilization of alkalies and the iron sintering at high gasification temperature may have also played a negative role on ash catalytic effect.

Experiments conducted in a high-temperature entrained flow gasifier showed the capability of this technology to obtain high gaseous product yield using noncatalytic steam gasification. This work was performed without $\mathrm{O}_{2}$ as first simplified approach. Prior to up scaling, experiments in the presence of $\mathrm{O}_{2}$ will be required.

Acknowledgment. The authors gratefully acknowledge the financial support from EnerBio Program of Fondation Tuck France and express their gratitude to Mr. Bernard AUDUC technician in Ecole des Mines d'Albi-Carmaux for his technical assistance and contribution to device design and operation. 